\title{
Fabrication of various carbon nanostructures by using different catalysts
}

\author{
Kang Ho Choi***, In Joon Yoo*, Hee Soo Lee**, Kyu Hwan Lee* and Dong Chan Lim*† \\ *Materials Processing Devision, Korea Institute of Materials Science, Changwon 641-931, Korea \\ **Pusan National Univ., Busan 609-735, Korea
}

(Received April 29, 2010)

(Revised May 24, 2010)

(Accepted June 4, 2010)

\begin{abstract}
Carbon fiber has many potential applications in a wide array of fields of solar cell, fuel cell, batteries, and polymer matrix composites due to an exceptional mechanical properties and chemical stability. In this study, the effects of catalysts on the property of carbon nanostructures grown on the carbon fiber were systematically investigated. The surface treatment of carbon fiber and catalysts synthesis for carbon nanostructures growth were carried out by one-pot ELP method and thermal CVD, respectively. The surface morphology and crystal structure of carbon nanostructures were examined using a field emission scanning electron microscope and transmission electron microscope. Depending on the type of catalysts and the molar ratio, various types of carbon nanostructures like carbon nanotube, carbon nanofilament, carbon nanospring and etc. were synthesized on the surface of carbon fibers surface.
\end{abstract}

Key words Thermal CVD, ELP, Carbon nanostructures, Carbon fiber

\section{촉매에 따른 다양한 탄소나노구조체 합성}

\author{
최강호***, 유인준*, 이희수**, 이규환*, 임동찬*t \\ *한국기계연구원부설 재료연구소 융합공정본부 전기화학연구그룹, 창원, 641-931 \\ ***부산대학교 재료공학부, 부산, 609-735
}

(2010년 4월 29일 접수)

(2010년 5월 24일 심사완료)

(2010년 6월 4일 게재확정)

요 약 탄소 섬유소재는 가벼우면서고 강건한 특성과 화학적 안정성 등으로 인해 항공기, 자동차, 레저, 우주항공, 풍력, 연료전지, 방위 산업 등의 분야를 비롯하여 최근에는 다양한 산업용 복합재료 및 보강용 분야에서 많이 사용되고 있다. 본 연구에서는 탄소섬유의 기능성 향상 및 다양한 응용 분야 확대를 위하여 물리적, 화학적 특성이 우수한 탄소나노튜브와 같 은 다양한 탄소나노구조체를 탄소섬유상에 하이브리드화 하는 연구를 진행하였다. ELP(Electroless plating)법을 이용하여 탄 소섬유 표면처리 및 촉매 입자 형성을 동시에 진행하였으며, Thermal CVD법을 이용하여 탄소나노구조체를 형성한 결과, 탄소섬유상 $\mathrm{Pd} / \mathrm{Ni}$ 복합 촉매의 비율에 따라서 탄소나노튜브, 탄소나노필라멘트 등 다양한 형태의 탄소섬유상 탄소나노구조 체가 형성되는 것을 알 수 있었다. $\mathrm{Pd}$ 촉매의 비율이 높을 수록 다중벽 탄소나노튜브(Multiwall carbon naotube)의 생성 비율 이 높아지고, $\mathrm{Ni}$ 촉매의 비율이 상대적으로 증가할 수록 탄소나노필라멘트(Carbon nanofilament)의 생성 비율이 높아짐을 알 수 있었다.

\section{1. 서 론}

탄소섬유는 경량화 및 높은 탄성계수, 낮은 열팽창계 수, 내부식성 등과 같은 고기능성을 가진 섬유로 그 응 용분야가 우주·항공, 방위산업 등 특정 산업분야에 벗어 나, 전기 · 전자, 육상 · 해상 수송, 토목 · 건축, 환경, 에

\footnotetext{
Corresponding author

Tel: +82-55-280-3511

Fax: +82-55-280-3570

E-mail: dclim@kims.re.kr
}

너지 등 전 산업 분야의 핵심소재로 용도가 적용 - 확대 되고 있다[1].

본 연구에서는 새로운 need에 능동적으로 대처하고, 기존 탄소 섬유의 성능 향상 및 신 기능을 부여할 수 있게 하기 위하여 탄소섬유상에 동일한 탄소계 나노구조 체를 형성하는 연구를 진행하였다.탄소섬유상에 탄소나 노구조체를 하이브리드화 하면 탄소섬유와 탄소나노구조 체의 우수한 특성을 동시에 부여할 수 있으며, 탄소나노 구조체의 종류에 따라 다양한 응용을 기대할 수 있다.

탄소나노구조체를 형성하기 위해서는 금속나노입자(촉 
매)의 특성이 무엇보다 중요하다. 촉매의 종류 및 크기 에 따라 탄소나노구조체의 종류 및 크기, 성장 모드가 모두 영향을 받게 된다[2-7]. 하이브리드 탄소섬유-탄소 나노구조체를 형성하기 위해서, 본 실험에서는 하이브리 드 탄소섬유-탄소나노구조체를 형성하기 위해서, 간단한 습식법을 이용하여 효율적으로 탄소섬유 표면에 촉매 입 자를 형성하는 연구를 진행하였으며, 특히 단일 촉매가 아닌 복합 촉매 형성을 통해 탄소섬유상에 탄소나노튜브, 탄소나노필라멘트, 탄소스프링 등 다양한 형태의 탄소나 노구조체를 합성하였다.

\section{2. 실험}

탄소섬유상 탄소나노구조체를 합성하기 위한 과정은 Fig. 1 같이 크게 두 가지 공정 순서로 진행된다. ELP (electroless plating)법을 이용한 탄소섬유 표면처리 및 탄소섬유상 금속나노입자 (촉매)를 형성한 후, 열 화학기 상증착법(Thermal CVD; chemical vapor deposition)방 법을 이용하여 탄소섬유상 탄소나노구조체를 합성한다 $[8,18]$.

\subsection{ELP(Electroless Plating)법을 이용한 탄소섬유상} 금속나노입자 형성

탄소섬유상에 고밀도의 탄소나노구조체를 균일하게 성 장시키기 위해서는 탄소섬유의 표면처리 및 촉매 형성 기술이 중요하다. 기존의 보고된 방법은 탄소섬유를 산 처리 등의 방법을 통해 표면 개질한 후, 진공 또는 습식 방법을 이용하여 $\mathrm{Ni}, \mathrm{Co}$ 등의 촉매입자를 기판에 형성 하였다. 또는 표면 개질의 과정 없이 진공 방식을 이용

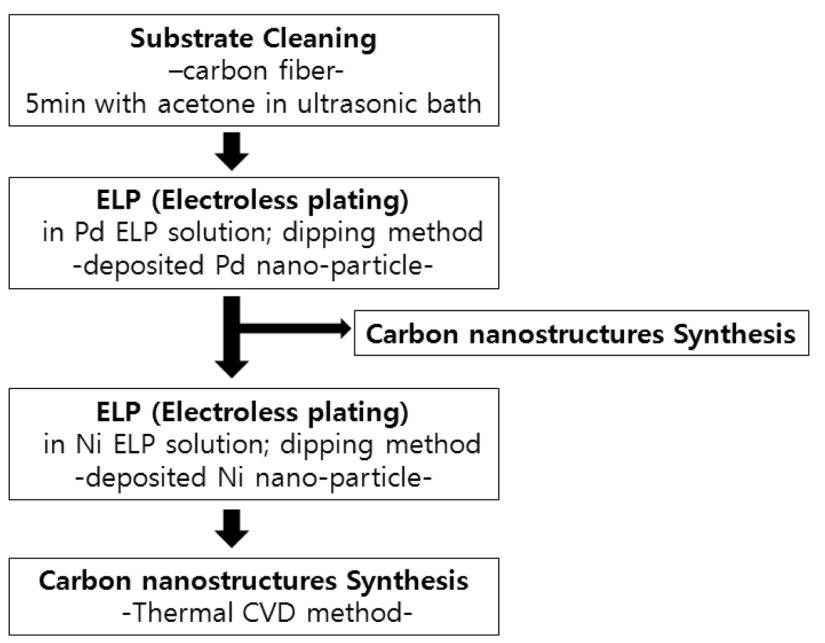

Fig. 2. A process of catalysts deposition followed by carbon nanostructures fabrication on carbon fiber.

하여 탄소섬유상에 직접 촉매를 형성한 후 탄소나노튜브 를 성장시키기도 하였다. 본 연구에서는 3차원 복잡 구 조 및 마이크로 단위의 표면 거칠기를 가지는 탄소섬유 기판에 금속나노입자(촉매)를 고르게 형성하기 위하여 ELP법을 이용하였다. ELP법이란 외부로부터 전기에너 지를 공급받지 않고 금속염 수용액 중의 금속이온을 환 원제의 힘에 의해 자기 촉매적으로 환원시켜 피처리물의 표면 위에 금속을 석출 시키는 방법으로 ELP법을 이용 하게 되면 기존의 두 단계의 촉매 형성 과정(탄소섬유 표면처리, 촉매 형성 과정)을 한 단계로 줄일 수 있으며, 표면처리 공정과 동시에 촉매를 균일하게 형성 할 수 있 어, 3차원의 복잡한 형태를 가지는 탄소섬유상에 촉매 입자를 고르게 형성 할 수 있다. Fig. 2와 같이 우선 $1.5 \times 1.5 \mathrm{~cm}^{2}$ 크기의 탄소섬유 페이퍼를 아세톤이 담긴 용기에 넣고 5 분간 초음파세척을 통하여 표면의 유기오

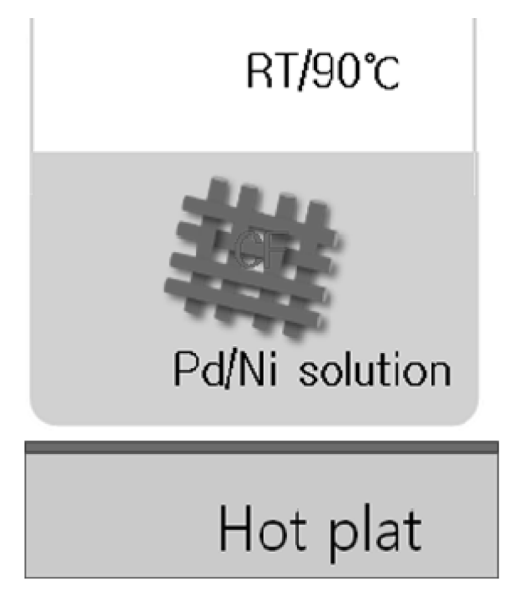

*Catalyst deposition process

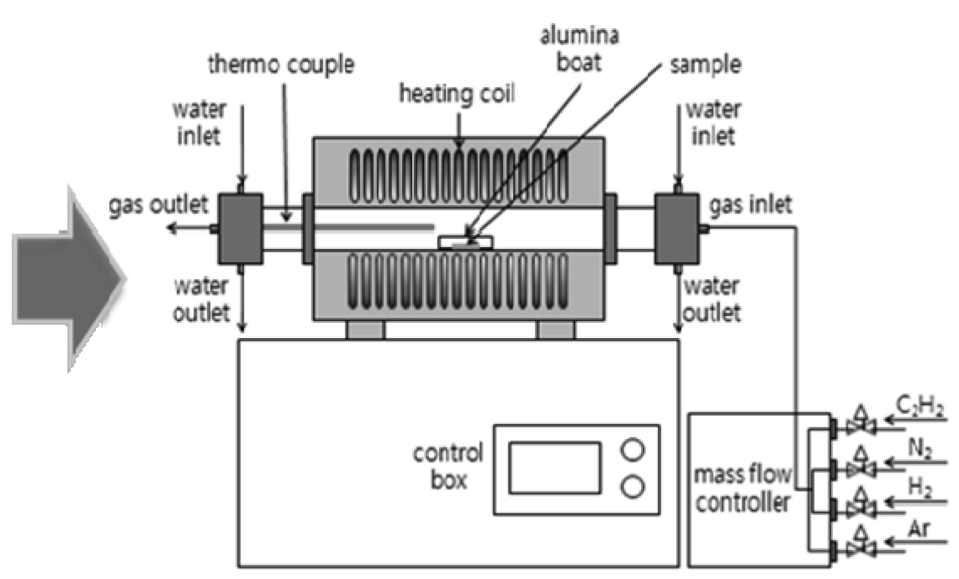

*Carbon nanostructures synthesis process

Fig. 1. Schematics diagram of experimental equipment for synthesis of carbon nanostructures. 
염물을 제거한 후[9], 준비된 ELP용액에 dip-coating하 여 탄소섬유상에 팔라듐 $(\mathrm{Pd})$ 및 니켈 $(\mathrm{Ni})$, 산화철 $\left(\mathrm{Fe}_{2} \mathrm{O}_{3}\right)$ 금속나노입자(촉매)를 형성하였다. ELP 용액 조성은 다 음과 같다.

- $\mathrm{Pd}$ 무전해도금액: [(PdCl2 : $1 \mathrm{ppm})+(\mathrm{HCl}: 3 \mathrm{ml} / \mathrm{L})$ + (HF : 5 ml.L)]; $\mathrm{pH} 2.0$

- Ni 무전해도금액: Uyemura사

상온 조건에서 필라듐(Pd) ELP액에 시편을 dip-coating/ dry 과정을 반복함으로써 탄소섬유상에 필라듐 나노입자 를 균일하게 형성 할 수 있으며, 증착밀도를 제어할 있 다. 한편 니켈 $(\mathrm{Ni})$ 나노입자는 전처리 공정을 마친 탄소 섬유 또는 앞선 공정을 통해Pd 나노입자가 도포된 탄소 섬유를 니켈 $(\mathrm{Ni}) \mathrm{ELP}$ 액에 $100^{\circ} \mathrm{C}$ 의 조건하에서 dipcoating 하여 형성하였다.

2.2. 열 화학기상증착법(Thermal Chemical Vapor Deposition)을 이용한 탄소섬유-탄소나노구조체 하이브리드

탄소섬유상 탄소나노구조체를 형성하기 위하여 Fig. 1 와 같은 열 화학기상증착(Thermal CVD) 장비를 이용하 였다. 장비는 크게 시편을 장착할 수 있는 Quartz tube, Heating coil을 이용한 가열로, 가열로의 온도를 조절할 수 있는 control box, Carrier 및 Reactive gas를 공급할 수 있는 MFC(Mass Flow Controller)로 구성되어 있다. 금속나노입자(촉매)가 형성된 탄소섬유 시편을 알루미나 도가니에 넣어 고정시킨 뒤 길이 $80 \mathrm{~cm}$, 직경 $5 \mathrm{~cm}$ 크 기의 quartz tube 안에 넣고, 캐리어 가스(Ar) 및 반응성 가스 $\left(\mathrm{C}_{2} \mathrm{H}_{2}, \mathrm{H}_{2}, \mathrm{Ar}, \mathrm{N}_{2}\right)$ 를 주입하여 가열로의 온도를 합 성 조건 온도까지 가열하여 탄소나노구조체를 합성하였 다[16]. 가열로의 온도 측정을 위하여 k-type thermocouple과 digital thermal sensor controller를 이용하였다. 시편을 가열로에 장착한 후 $\mathrm{Ar}$ 가스 $(500 \mathrm{sccm})$ 로 반응 용기를 채워 용기 안을 $\mathrm{Ar}$ 분위기로 만든다음, 이후 가 열로의 온도를 $500^{\circ} \mathrm{C}$ 까지 올리고, 시편 표면의 유기물 등의 불순물 제거 및 촉매 환원을 위해 $\mathrm{H}_{2}$ 가스를 100 $\mathrm{sccm}$ 주입하여 1 시간 동안 전처리 과정을 진행하였다
[12]. 전처리 공정을 마친 후 탄소나노구조체를 합성하기 위하여 가열로의 온도를 $550^{\circ} \mathrm{C}$ 로 올리고, 각각의 반응성 가스를 다음과 같은 비율 $\left(\mathrm{C}_{2} \mathrm{H}_{2}: \mathrm{H}_{2}: \mathrm{Ar}: \mathrm{N}_{2}=1: 5: 35\right.$ : 2.3)로 $\mathrm{MFC}$ 를 이용하여 가열로 안으로 주입하였다 $[8$, 15]. 탄소나노구조체를 형성하기 위한 합성 시간은 3 6 분으로 조절하였다. 탄소나노구조체를 합성한 후 $\mathrm{C}_{2} \mathrm{H}_{2}$ 가스와 $\mathrm{H}_{2}$ 가스의 주입을 멈추고 $\mathrm{Ar}, \mathrm{N}_{2}$ 를 $1: 9$ 의 비율 로 혼합하여 흘려주면서 상온으로 냉각하였다. $\mathrm{Ar}$ 과 $\mathrm{N}_{2}$ 가스의 주입을 통해 냉각 과정 동안 유입되는 공기 중의 불순물로부터 탄소나노구조체의 특성 및 표면상태가 변 질되는 것을 막을 수 있게 된다 $[10,11,13,14,19]$. 합성 된 탄소나노구조체는 FE-SEM(JSM-6700F, JEOL, Japan), TEM(JEM-2100F，JEOL，Japan) 및 BET(BELSORP $\operatorname{mini} 2$ ) 측정을 이용하여 구조적 특성을 확인하였다 $[17,20]$.

\section{3. 결과 및 토의}

탄소섬유상에 탄소나노구조체를 형성, 특성을 제어하 기 위해서는 탄소섬유상에 금속나노입자(촉매)를 균일하 게 증착시켜야 한다[7]. 탄소섬유 응용 제품은 Fig. 3(a) 와 같이 3차원의 복잡한 구조를 가지고 있기 때문에 일 반적인 금속나노입자 형성 방법인 스퍼터링(sputtering) 혹은 화학기상증착(chemical vapor deposition)[21-25] 등의 방법으로는 탄소섬유의 표면 아래층까지 균일한 금 속나노입자(촉매)층을 형성할 수가 없다.

따라서 본 연구에서는 앞서 실험 방법과 같이 간단한 용액 공정(ELP법)을 이용하여 탄소섬유상에 균일한 분 포를 가지는 금속나노입자(촉매)를 형성하였다. 탄소나노 구조체를 형성하기 위한 촉매로 사용되는 금속나노입자 는 $\mathrm{Fe}_{2} \mathrm{O}_{3}, \mathrm{Co}, \mathrm{Pd}, \mathrm{Ni}$ 등이 있으며, 본 연구에서는 습식 법을 이용하여 탄소섬유상에 $\mathrm{Fe}_{2} \mathrm{O}_{3}, \mathrm{Pd}, \mathrm{Ni}$ 촉매입자를 형성하고 탄소나노구조체를 형성하였다. 특히 ELP법 및 일반 습식법의 비교를 위하여 탄소섬유상에 $\mathrm{Fe}_{2} \mathrm{O}_{3}$ 나노 입자를 분산 용액인 IPA(Isopropyl alcohol)에 넣고 초음

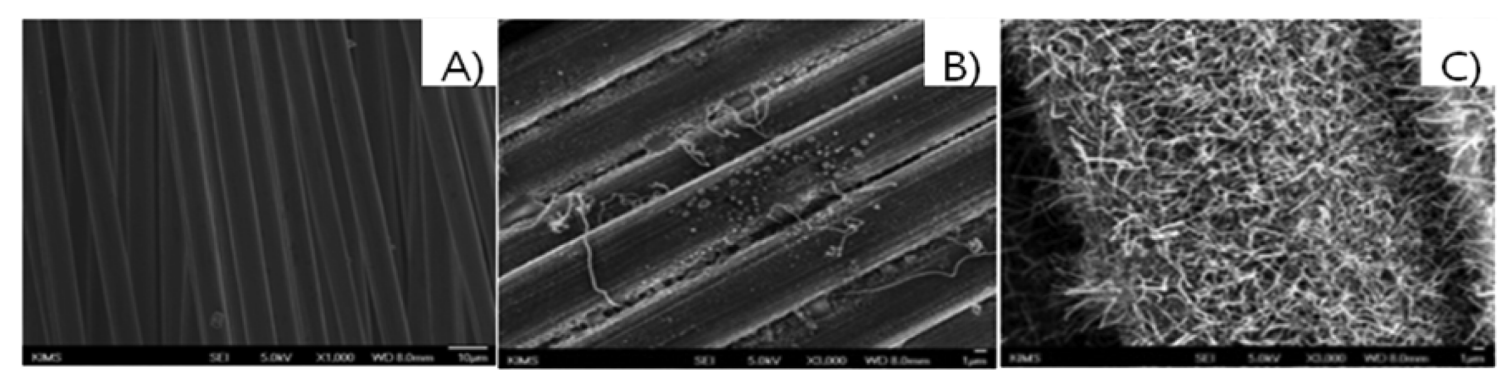

Fig. 3. SEM images of (a) as-prepared carbon fiber, (b) carbon nanostructure on carbon fiber with $\mathrm{Fe}_{2} \mathrm{O}_{3}$ as a catalyst, and (c) carbon nanostructure on carbon fiber with $\mathrm{Pd}$ as a catalyst. 
파 분산기를 이용하여 1 시간 동안 분산 후 준비된 탄소 섬유 시편을 용액에 침지하여 탄소섬유상에 $\mathrm{Fe}_{2} \mathrm{O}_{3}$ 촉매 입자를 형성하고, 드라이과정을 마친 후, 상기 탄소나노 구조체 형성 방법을 이용하여 탄소나노구조체를 합성하 였다. Fig. 3(b)는 $\mathrm{Fe}_{2} \mathrm{O}_{3}$ 를 촉매로 사용하여 합성한 탄소 섬유상 탄소나노구조체의 SEM 이미지이다. 탄소섬유상 에 $\mathrm{Fe}_{2} \mathrm{O}_{3}$ 촉매가 균일하게 형성되지 않고, 탄소나노구조 체가 거의 형성 되지 않은 것을 확인 할 수 있다. 따라 서 탄소섬유상에 습식법을 이용하여 촉매 나노입자를 균 일하게 형성하기 위한 방법으로 상기의 ELP법을 이용하 여 탄소섬유상에 촉매 나노입자를 형성하였다. 산성의 ELP 용액은 탄소섬유 표면을 개질함과 동시에 금속나노 입자(촉매)를 균일하게 형성할 수 있는 장점을 지니고 있음을 확인하였다. $\mathrm{pH} 2.0$ 의 Pd ELP액을 준비하고, 상 기 실험 방법을 이용하여 탄소섬유상에 $\mathrm{Pd}$ 촉매를 형성 하고, 탄소나노구조체를 형성하였다. Fig. 3(c)는 Pd를 촉매로 사용하여 합성한 탄소섬유상 탄소나노구조체의 $\mathrm{SEM}$ 이미지이다. 탄소섬유상에 탄소나노구조체가 높은 형성분포밀도로 균일하게 성장되어 있는 것을 확인 할 수 있다. 따라서 이와 같은 산성의 ELP액을 이용한 전 처리 및 촉매 형성법은 3 차원의 복잡한 구조를 가진 탄 소섬유상에 고밀도의 금속나노입자나 탄소나노구조체를

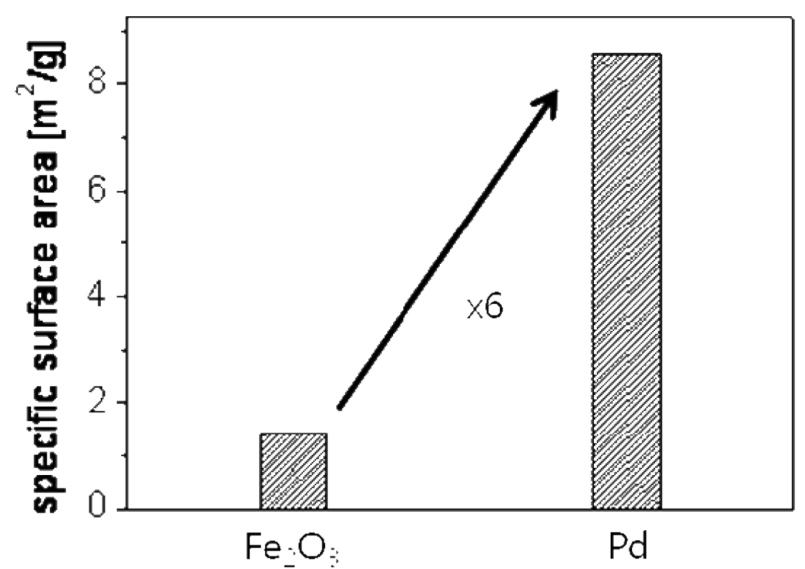

Fig. 4. BET results of carbon nanostructures on carbon fiber depending on the type of catalysts.

쉽게 형성할 수 있는 유용한 방법임을 알 수 있었다. Fig. 4는 각각의 촉매 형성을 이용하여 탄소섬유상에 성 장된 탄소나노구조체의 비표면적 측정(BET; Brunauer, Emmett, and Teller) 결과를 보여준다. Fig. 3의 SEM 결과와 같이 산성의 ELP액을 이용한 전처리 및 촉매 형 성법을 이용한 경우, 다른 습식법에 의해 합성한 탄소섬 유-탄소나노구조체 하이브리드 시편에 비해 비표면적이 6

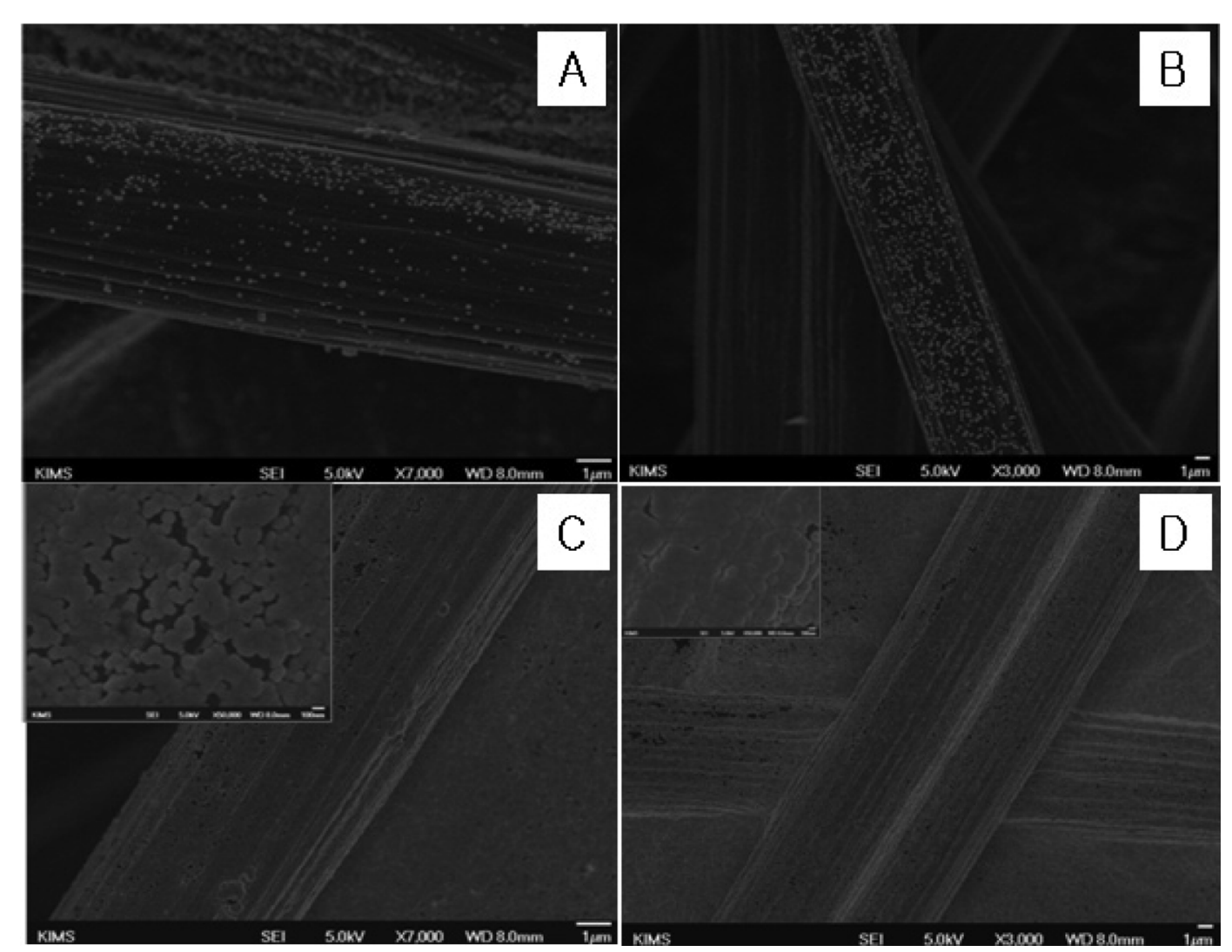

Fig. 5. SEM images of $\mathrm{Pd}$ and $\mathrm{Ni}$ catalysts on carbon fiber under (a) $\mathrm{Pd}: \mathrm{Ni}=1: 1$, (b) $\mathrm{Pd}: \mathrm{Ni}=1: 2$, (c) $\mathrm{Pd}: \mathrm{Ni}=1: 4$, (d) $\mathrm{Pd}: \mathrm{Ni}=1: 12$. 
배나 높은 탄소섬유-탄소나노구조체 하이드리드 소재를 형성할 수 있음을 알 수 있다.

한편 $\mathrm{Pd}$ 나노입자는 탄소나노구조체를 형성하기 위한 촉매로 작용 할 수 있을 뿐만 아니라, 화학적 안정성 및 기타 금속나노입자와의 친화력을 가지고 있기 때문에 기 타 금속나노입자를 형성하기 위한 seed로 사용될 수 있 다[36]. 본 연구에서는 $\mathrm{Pd}$ 나노입자를 이용하여 Fig. 5 와 같이 $\mathrm{Ni}$ 나노입자를 형성하였다. Fig. 5는 탄소섬유 시편을 $\mathrm{Pd}$ 및 $\mathrm{Ni} \mathrm{ELP}$ 액에 침지하는 시간에 따라 다르 게 형성된 탄소섬유상-촉매의 FE-SEM 이미지이다. Ni 나노입자는 앞서 설명한 산화철 나노입자와 같이 $\mathrm{Pd}$ ELP전처리 과정을 하지 않을 경우에는 탄소섬유상에 균 일하게 성장되지 못하였다. 그러나 탄소섬유상에 $\mathrm{Pd}$ 나 노입자를 형성한 후, Ni ELP법을 적용할 경우 Fig. 5와 같이 높은 증착밀도의 $\mathrm{Ni}$ 촉매 나노입자를 탄소섬유상 에 형성할 수 있었다. 특히 Fig. 5의 $\mathrm{A}$ 와 $\mathrm{B}$ 와 같이 $\mathrm{Pd}$ 의 dipping 시간을 조절하게 되면 $\mathrm{Ni}$ 나노입자 형성 시 간을 동일하게 유지하더라도 상대적으로 높은 증착밀도 의 $\mathrm{Ni}$ 촉매 나노입자를 형성할 수 있다. 한편 Fig. 5의
$\mathrm{A}, \mathrm{C}$ 와 같이 $\mathrm{Pd}$ 의 양을 동일하게 유지하고, $\mathrm{Ni}$ 나노입 자 형성 시간을 다르게 하여도 그림과 같이 $\mathrm{Ni}$ 촉매 나 노입자의 증착밀도를 조절할 수 있었다.

그리고 $\mathrm{Pd}$ 과 $\mathrm{Ni}$ 의 $\mathrm{ELP}$ 액 dipping 시간을 충분히 늘 려주면, Fig. $5 \mathrm{D}$ 와 같이 탄소섬유 표면을 촉매입자로 균 일하게 코팅 할 수 있었다. 이와 같은 ELP법을 이용한 촉매 나노입자 형성 방법은 기타 진공 방법에 비하여 탄 소섬유와 같이 3 차원의 복잡한 형상을 가진 시편 위에 도 고르게 나노입자를 형성 할 수 있을 뿐만 아니라, 증 착밀도 조절이 용이하고, 공정 시간을 단축할 수 있는 장점을 가지고 있었다. 특히 단일 촉매가 아닌 2종 이상 의 복합 촉매를 형성할 수 있는데, 복합 촉매는 촉매의 조성비에 따라서 다양한 형태의 탄소나노구조체를 형성 할 수 있었다. Fig. 6은 Fig. 5의 탄소섬유상 $\mathrm{Pd}$ 및 $\mathrm{Ni}$ 촉매 나노입자 형성 방법 및 결과를 바탕으로 탄소섬유 상에 $\mathrm{Pd}$ 및 $\mathrm{Ni}$ 촉매 나노입자를 상대적 비율로 형성한 후 동일한 조건하에서 형성된 탄소나노구조체의 $\mathrm{FE}-$ SEM 및 TEM 이미지이다. Fig. 5의 결과와 같이 $\mathrm{Pd}$ 및 $\mathrm{Ni}$ 촉매 나노입자의 상대적인 비율에 따라 탄소섬유상에

\section{Pd rich}

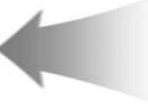

Pd-Ni Catalysts
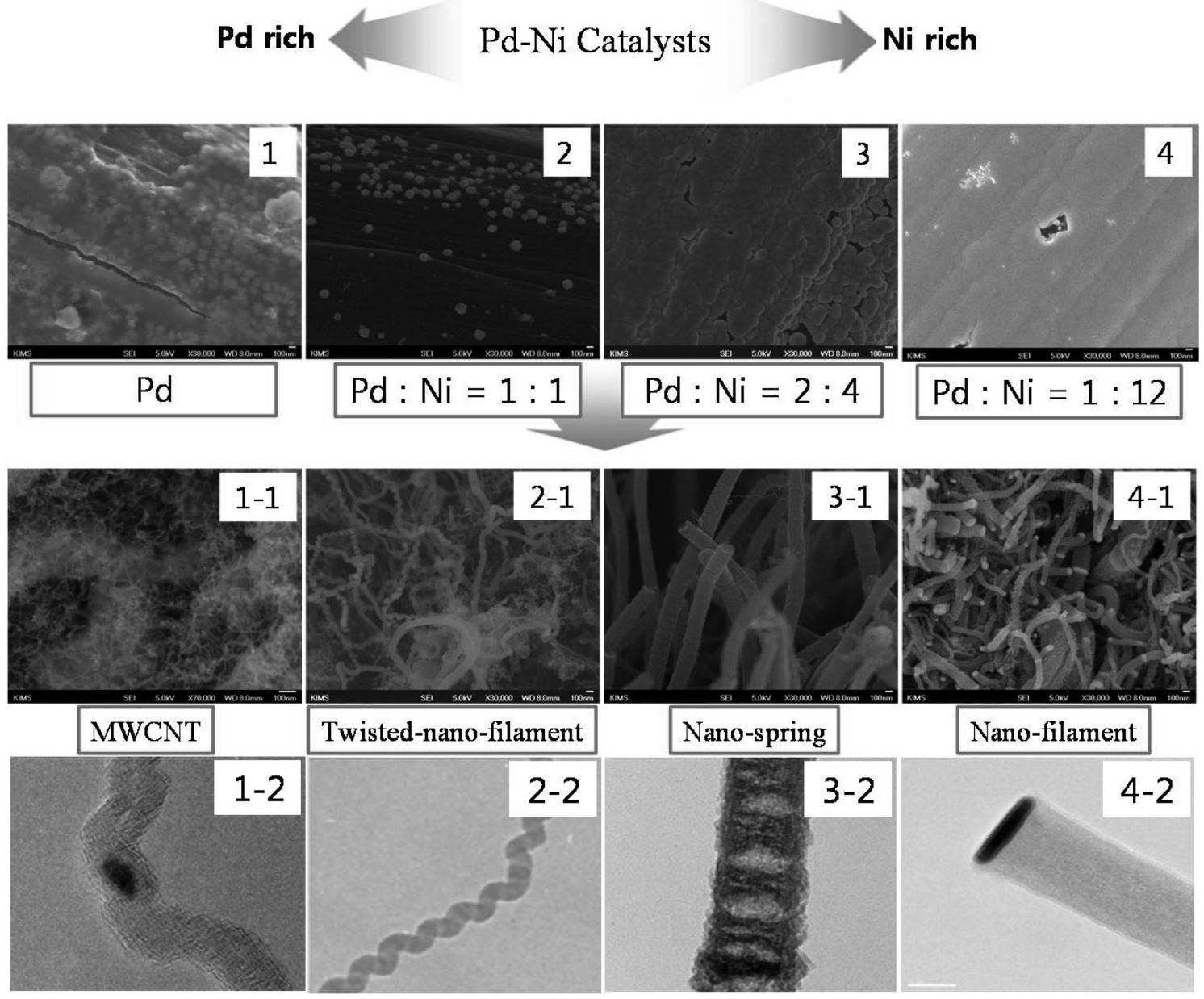

Nano-filament

Fig. 6. SEM and TEM images of carbon fiber depend on the molar ration of $\mathrm{Ni}$ and Pd catalysts. 

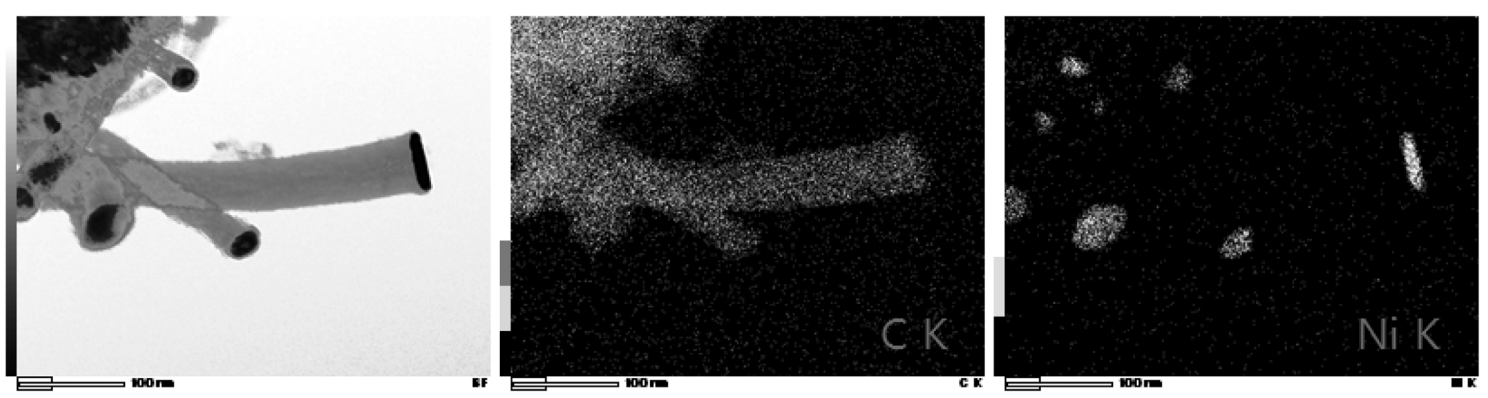

Fig. 7. The growth mode of carbon nanostructures on the carbon fiber (TEM and EDX mapping).

형성된 촉매의 증착밀도가 달라짐을 볼 수 있다. 그러나 각각의 경우에 동일하게 높은 형성분포밀도를 가지는 탄 소나노구조체가 형성됨을 알 수 있다. 특히 촉매의 비율 에 따라 다양한 형태의 탄소나노구조체가 형성됨을 볼 수 있다. 탄소섬유상 $\mathrm{Pd}$ 촉매만 있는 경우에는 Fig. 6 1-1 및 1-2에서 보듯이 8개의 벽을 가진 다중벽 탄소나 노튜브(Multi-wall carbon nanotube)가 주로 형성됨을 볼 수 있다.

그리고 $\mathrm{Ni}$ 촉매만 탄소섬유 표면을 충분히 덮고 있는 경우에는 두께 약 $20 \mathrm{~nm}$ 의 나노필라멘트(Nanofilament) 형태의 탄소구조체가 형성됨을 볼 수 있다. 일반적으로 탄소나노구조체가 형성되는 성장거동은 크게 두 가지로 분류 할 수 있다. 탄소나노구조체가 기판으로부터 성장 하는 동안 기판에 형성되어 있는 촉매를 밀어 올려서 성 장되는 top growth와 촉매를 기준으로 위로 성장하는 down growth이다. 일반적으로는(열 화학기상증착법) 후 자의 경우가 주로 형성되지만[26], 본 연구에서는 Fig. 7 에서와 같이 top growth의 성장 거동을 보임을 알 수 있다. 이와 같은 결과는, ELP법을 이용하여 탄소섬유상 에 형성된 촉매 나노입자가 탄소나노구조체를 형성하기 위한 공정 온도 조건에서 탄소섬유로 diffusion 되어 들 어가지 않으며, 또한 탄소섬유와 화학적으로 강한 결합 을 하여 변형되지 않았음을 보여준다. 따라서 결과적으 로 상기실험에서 top growth의 성장거동으로 촉매금속 이 탄소나노구조체의 상부에 위치하여, down growth 성 장거동처럼 촉매금속이 탄소섬유와 탄소나노구조체 사이 에 존재하지 않아서, 탄소섬유가 직접적으로 탄소나노구 조체와 결합을 형성할 수 있게 된다.

한편 $\mathrm{Pd}$ 촉매 위에 형성된 $\mathrm{Ni}$ 촉매 나노입자는 탄소 나노구조체를 형성하는 공정 온도 $\left(550^{\circ} \mathrm{C}\right)$ 조건하에서 합 금이 형성되며 각각의 조성 분율은 Fig. 8에 나타낸 바 와 같이 공정 조건에 따라 규칙적으로 변하는 것을 확인 할 수 있었다. 이와 같은 각각의 조건하에서 형성된 탄 소나노구조체는 Fig. 6의 2-1, 2-2에서와 같이 약 $100 \mathrm{~nm}$ 두께의 twisted nanofilament 또는 3-1, 3-2에서와 같은 두께 약 $150 \mathrm{~nm}$ 의 stack-cup(nano-spring) 나노구조체가

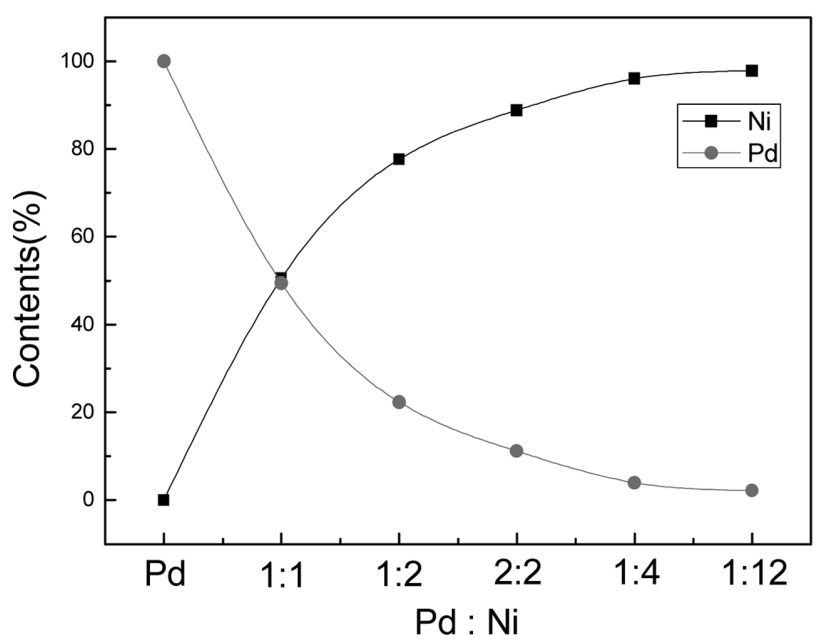

Fig. 8. The compositions of $\mathrm{Pd}$ and Ni catalyst under different conditions.

주로 형성됨을 볼 수 있었다.

탄소나노튜브를 합성할 때, 촉매의 크기가 나노튜브의 직경을 결정하는데 큰 역할을 하는 것은 익히 알려져 있 는 사실이며 [26-32], 촉매의 종류에 따라 SWCNT(single wall carbon nanotube), DWCNT(double wall carbon nanotube), MWCNT(multi wall carbon nanotube), CF (carbon nanofilament), carbon nanospring, spiral shape carbon nanotube등 다양한 구조체가 합성되는 것은 문헌 을 통해 보고되고 있으나[33-35], 상기와 같이 탄소섬유 상에 복합촉매의 비율 조절을 통해 탄소나노튜브, 탄소 나노필라멘트 등, 탄소나노구조체의 종류를 선택적으로 제어할 수 있음을 알았다.

\section{4. 결 론}

하이브리드 탄소섬유-탄소나노구조체 합성을 위해 ELP법을 이용하여 탄소섬유상에 촉매금속을 증착시킨 후, Thermal CVD법을 이용하여 탄소섬유상에 탄소나노 구조체를 성장시켰다. 본 실험에서 사용한 ELP법은 간 
단한 습식법으로써 복잡한 3차원 구조의 탄소섬유상에 표면처리 및 촉매형성을 one-step으로 진행하여, 금속나 노입자(촉매)를 균일하게 형성할 수 있었으며 전체적 공 정의 수를 줄이는 역할을 하였다. 또한 ELP법은 조성을 쉽게 제어하여 복합촉매를 탄소섬유 표면에 균일하게 형 성할 수 있었다. 이렇게 ELP법으로 증착 시킨 복합촉매 형성을 통해 다양한 형태의 탄소나노구조체를 선택적으 로 성장시킬 수 있었다. 복합촉매의 비율에 따라 여러가 지 형상이 나타났는데, $\mathrm{Ni}$ 의 비율이 높을수록 탄소나노 필라멘트의 구조가, $\mathrm{Pd}$ 의 비율이 높을수록 다중벽탄소나 노튜브가 형성됨을 확인할 수 있었다. 이론적 연구에 따 르면 촉매 입자의 방향성과 생성된 나노구조체의 축 사 이에 상관관계가 존재함이 나타났고, 니켈에서 일어나는 탄화수소의 분해가 니켈의 비등방성 때문에 나노입자의 면에 따라 다르게 일어나는 것으로 관찰되었다. 탄소나 노구조체의 성장과정에서 탄소 네트워크와 촉매 금속 원 자들의 구조 사이에 상호 작용이 있는 것으로서 결정 방 향성이 chirality를 결정하는 중요한 역할을 하는 것으로 보고 되고 있다. 본 연구의 복합촉매와 탄소나노구조체 의 상호작용에 대한 연구가 수행 중에 있다. 이러한 선 택적 탄소섬유-탄소나노구조체 하이브리드 섬유 개발은 향후 복합재, 수소저장, 및 태양전지용 전극 슈퍼캐패시 터, 환경 촉매 등 다양한 분야에 적용될 수 있으리라 예 상된다.

\section{감사의 글}

This research was supported by a grant from the Fundamental R\&D Program for Core Technology of Materials funded by the Ministry of Knowledge Economy, Republic of Korea.

\section{참 고 문 헌}

[1] D.D. Edie, "The effect of processing on the structure and properties of carbon fibers", Carbon 36 (1998) 345.

[2] S. Iijima, "Helical microtubules of graphitic carbon", Nature 354 (1991) 56.

[ 3 ] H. Takikawa, M. Yatsuki, T. Sakakibara and S. Itoh, "Carbon nanotubes in cathodic vacuum arc discharge", Journal of Physics D: Applied Physics 33 (2000) 826.

[ 4 ] Z.P. Huang, J.W. Wu, Z.F. Ren, J.H. Wang, M.P. Siegal and P.N. Provencio, "Growth of highly oriented carbon nanotubes by plasma-enhanced hot filament chemical vapor deposition”, Applied Physics Letters 73 (1998) 3845.

[ 5 ] A.A. Puretzky, D.B. Geohegan, X. Fan and S.J. Pennycook, "Dynamics of single-wall carbon nanotube syn- thesis by laser vaporization", Applied Physics A: Materials Science and Processing 70 (2000) 153.

[6] Q. Zhang, S.F. Yoon, J. Ahn, B. Gan, Rusli, M.B. Yu, L.K. Cheah and X. Shi, "Field emission from carbon nanotubes produced using microwave plasma assisted CVD", International Journal of Modern Physics B 14 (2000) 289.

[ 7 ] A.C. Dupuis, "The catalyst in the CCVD of carbon nanotubes-a review", Progress in Materials Science 50 (2005) 929.

[8] S.I. Yang, "Structural study using ultrahigh resolution carbon nanotube AFM probe tips", Journal of the Korean Chemical Society 49 (2005) 517.

[9] C.E. Baddour, F. Fadlallah, D. Nasuhoglu, R. Mitra, L. Vandsburger and J.-L. Meunier, "A simple thermal CVD method for carbon nanotube synthesis on stainless steel 304 without the addition of an extermal catalyst", Carbon 47 (2009) 313.

[10] Z. Zhang, M. Shakerzadeh, B. Tay, X. Li, C. Tan, L. Lin, P. Guo, T. Feng and Z. Sun, "Fabrication of aligned carbon nanotubes on $\mathrm{Cu}$ catalyst by dc plasma-enhanced catalytic decomposition", Applied Surface Science 255 (2009) 6404.

[11] A. AgIral, L. Lefferts and J.GE. Gardeniers, "In situ CVD of carbon nanofibers in a microreactor", Catalysis Today 150 (2010) 128.

[12] N. Zhao, Q. Cui, C. He, C. Shi, J. Li, H. Li and X. Du, "Synthesis of carbon nanostructures with different morphologies by CVD of methane", Materials Science and Engineering A 460-461 (2007) 255.

[13] R.L. Vander Wal and L.J. Hall, "Carbon nanotube synthesis upon stainless steel meshes", Carbon 41 (2003) 659.

[14] V. MartıLnez-Hansen, N. Latorre, C. Royo, E. Romeo, E. GarciLa-Bordeje and A. Monzo, "Development of aligned carbon nanotubes layers over stainless steel mesh monoliths", Catalysis Today 147 (2009) 71.

[15] Y. Ferna'ndez, B. Fidalgo, A. Domı'nguez, A. Arenillas and J.A. Mene'ndez, "Carbon nanofilament synthesis by the decomposition of $\mathrm{CH}_{4} / \mathrm{CO}_{2}$ under microwave heating", Carbon 45 (2007) 1696.

[16] S.K. Pillai, L. Mathoko, C. Arendse, S. Sinha Ray and M. Moodley, "The use of calcination in exposing the entrapped Fe particles from multi-walled carbon nanotubes grown by chemical vapor deposition", Applied Physics A: Materials Science and Processing 94 (2009) 585.

[17] M.-F. Fiawoo, A.-M. Bonnot, V. Jourdain, T. Michel, M. Picher, R. Arenal, J. Thibault-Pénisson and A. Loiseau, "Substrate preparation techniques for direct investigation by TEM of single wall carbon nanotubes grown by chemical vapor deposition", Surface Science 603 (2009) 1115.

[18] M. Meyyappan, L. Delzeit, A. Cassell and D. Hash, "Carbon nanotube growth by PECVD: a review", Plasma Sources Science and Technology 12 (2003) 205.

[19] A.G. Nasibulin, P.V. Pikhitsa, P. Queipo, M. Choi and E.I. Kauppinen, "Investigations of mechanism of carbon nanotube growth", Physica Status Solidi (B) Basic Research 13 (2006) 3095.

[20] D. Takagi, Y. Kobayashi and Y. Homma, "Carbon nano- 
tube growth from diamond", Journal of the America Chemical Society 131 (2009) 6922.

[21] Z.Y. Juang, J.F. Lai, C.H. Weng, J.H. Lee, H.J. Lai, T.S. Lai and C.H. Tsai, "On the kinetic of carbon nanotube growth by thermal CVD method", Diamond \& Related Materials 13 (2004) 2140.

[22] N.K. Chang and S.H. Chang, "High-yield synthesis of carbon nanocoils on stainless steel", Carbon 46 (2008) 1091.

[23] T. Hashishin and J. Tamaki, "Au-Pd catalyzed growth of carbon nanofibers mat", Materials Chemistry and Physics 111 (2008) 54.

[24] W. Wunderlich, "Growth model for plasma-CVD growth of carbon nano-tubes on Ni-sheets", Diamond \& Related Materials 16 (2007) 369.

[25] T. Hirata, N. Sakate, GH. Jeong, T. Kato, R. Hatakeyama, K. Motomiya and L. Tohji, "Magnetron-type radio-frequency plasma control yielding vertically well-aligned carbon nanotube growth", Applied Physics Letters 83 (2003) 1119.

[26] A.M. Pantano, D. Parks and M.C. Boyce, "Mechanics of deformation single- and multi-wall carbon nanotubes", Journal of the Mechanics and Physcis of Solids 52 (2004) 789.

[27] P. Delhaes, M. Couzi, M. Trinquecoste, J. Dentzer, H. Hamidou and C. Vix-Guterl, "A comparison between Raman spectroscopy and surface characterizations of multiwall carbon nanotubes", Carbon 44 (2006) 3005.

[28] Z. Zhang, D.H.C. Chua, Y. Gao, Y. Zhang, Z. Tang, B.K. Tay, T. Feng, Z. Sun and Y. Chen, "Field-emission properties of carbon nanotubes grown using $\mathrm{Cu}-\mathrm{Cr}$ catalysts", Journal of Vacuum Science and Technology
27 (2009) 41.

[29] B. Gan, J. Ahn, Q. Zhang, Rusli, S.F. Yoon and J. Yu, "Y-junction carbon nanotubes grown by in situ evaporated copper catalyst", Chemical and Physics Letters 333 (2001) 23.

[30] Y. Li, B. Zhang, X. Xie, J. Liu, Y. Xu and W. Shen, "Novel Ni catalysts for methane decomposition to hydrogen and carbon nanofibers", Journal of Catalysis 238 (2006) 412.

[31] S. Takenaka, S. Kobayashi, H. Ogihara and K. Otsuka, " $\mathrm{Ni} / \mathrm{SiO}_{2}$ catalyst effective for methane decomposition into hydrogen and carbon nanofiber", Journal of Catalysis 217 (2003) 79.

[32] K. Otsuka, H. Ogihara and S. Takenaka, "Decomposition of methane over Ni catalysts supported on carbon fibers formed from different hydrocarbons", Carbon 41 (2003) 223.

[33] S.P. Sharma and S.C. Lakkad, "Morphology study of carbon nanospecies grown on carbon fibers by thermal CVD technique", Surface \& Coatings Technology 203 (2009) 1329.

[34] J. Li, C. Papadopoulos and J. Xu, "Nanoelectronics: Growing Y-junction carbon nanotubes", Nature 402 (1999) 253.

[35] J.-M. Ting and R.-M. Liu, "Carbon nanowires with new microstructures", Carbon 41 (2003) 625.

[36] J.Y. Kim, Y. Jo, S.-K. Kook, S. Lee and H.C. Choi, "Synthesis of carbon nanotube supported Pd catalysts and evaluation of their catalytic properties for $\mathrm{C}-\mathrm{C}$ bond forming reactions", Journal of Molecular Catalysis A 323 (2010) 28. 